\title{
Socratic Irony and Argumentation
}

\author{
Timo Airaksinen ${ }^{1,2}$ (D)
}

Accepted: 14 October 2021 / Published online: 6 November 2021

(c) The Author(s) 2021

\begin{abstract}
Socratic irony can be understood independently of the immortal heroics of Plato's Socrates. We need a systematic account and criticism of it both as a debate-winning strategy of argumentation and teaching method. The Speaker introduces an issue pretending to be at a lower intellectual level than her co-debaters, or Participants. An Audience looks over and evaluates the results. How is it possible that the Speaker like Socrates is, consistently, in the winning position? The situation is ironic because the Participants fight from a losing position but realize it too late. Socratic irony compares with divine irony: divine irony is a subtype of Socratic irony since you lose when you challenge gods. Socratic irony is also, prima facie, a subtype of dramatic irony when the Audience knows more than the Participants on the stage. We must distinguish between the ideal and realistic elements of Socratic Irony. The very idea of Socratic irony looks idealized, or it is an ideal case, which explains the Speaker's consistently winning position. In real life, the debate must be rigged, or the Dutch Book argument applies to the Participants, if the Speaker is so successful.
\end{abstract}

Keywords Dramatic irony $\cdot$ Divine irony $\cdot$ Know-how $\cdot$ Know-that $\cdot$ Persuasion Teaching $\cdot$ Rhetoric $\cdot$ Power

\section{Introduction to Socratic Irony}

The idea of irony entails that the surface sentence meaning and the deeper meaning are not the same. According to The American Heritage Dictionary, irony contains an "incongruity between what might be expected and what actually occurs." A dictionary definition of Socratic irony is as follows: the Socratic Speaker pretends to be

\footnotetext{
1 These typical, elementary characterizations cannot distinguish between, say, irony and metaphor; see Nathan, "Irony, Metaphor, and the Problem of Intention," (1992).

Timo Airaksinen

timo.airaksinen@helsinki.fi

1 Philosophy Department, University of Helsinki, 00014 Helsinki, Finland

2 Present Address: Philosophy Department, University of Helsinki, Susitie 10 C 32, 00800 Helsinki, Finland
} 
ignorant because she wants to show someone else is ignorant and incapable of solving the problem in question. She may then present her solution. Socratic irony (abbr. SI) involves Participants who have a preassigned losing role in the debate against the Speaker; they do not know they cannot win. However, this irony is different from the dictionary definition that focuses on the initial moves in a debate. Let us call it type-A irony. Type-B irony follows from the systematic losing role of the Participants. We find a preassigned winner, historically Plato's Socrates.

The standard meaning of Socratic irony covers the A-type only, but the B-type is a natural extension of it: A leads to B. The key point of the B-type is the Speaker's superior success: Socrates is the wisest living person, and his A-type irony is the key to the method that allows him to shine, that is, it is consistently the winning strategy - this is B-type Socratic irony. Therefore, we discuss a method of argumentation that utilizes SI: it contains two parts: (A) the speaker pretends she does not know and that (B) leads to her success. ${ }^{2}$ In this way, we identify a Socratic method of debating and arguing based on SI. Are the A and B types of SI linked or independent? They are systematically linked so that "SI" refers to both of them and A and B specify two aspects of SI.

Of course, any real-life debater may begin by declaring her ignorance, but here the Participants' consistent losing position must be an idealization-no "Socrates" can always win. Therefore, the A-type SI has its ideal aspects as well: it is a winning strategy. Therefore, SI is a combination of A- and B-type irony. In other words, we discuss the A-type of SI as a winning strategy, which is then expressed by the idea of the B-type. The Speaker wins (B) after ironizing her initial moves (A). SI is a model of a certain type of debate and its conclusions. In real life, the outcome of a fair debate is typically unpredictable.

At first sight, the Socratic situation looks unrealistic because of its ideal elements, that is, the preassigned roles of winners and losers. We need to explain what these elements and the roles are. What can guarantee the typical outcome of the debate? Could a historical agent, Socrates, be such a perennial winner? That does not sound realistic but given some ideal features, this type of winner can be called Socrates. The conclusion is that Socrates cannot be a real-life person but an ideal type of debater. Yet, the students of Socratic irony normally treat Socrates as a real person, or as far as he is an invention of Plato, a possible person. Plato's Socrates practices Socratic irony, but he is also ironized by Aristophanes-the result is multiple ironies: the great ironist himself is a victim of biting irony. ${ }^{3}$ Xenophon's Socrates is a philosopher, though. ${ }^{4}$ It is not necessary to study these various Socratic images here.

If Plato's Socrates practiced SI, we also should tell what he practiced without knowing the interpretative tradition or even mentioning him. However, Socratic

\footnotetext{
${ }^{2}$ Socratic irony is a method; one uses irony aiming at a goal, but we also speak of being ironic. Hence, irony is a mode of being, of being an ironist; see Rorty, Contingency, Irony, and Solidarity, (1989, pp. 74-75).

3 See Aristophanes, Clouds.

4 Xenophon in his Apology (Sec. 3) reports Socrates' words: "Why, do I not seem to you to have spent my whole life in preparing to defend myself?" No longer is he an ironist; he has been defending himself!
} 
irony is almost exclusively discussed in classical studies as something Socrates practiced. G. R. F. Ferrari explains the position of the Classicists: "[T]heir tendency has been to turn immediately to what Socrates' irony has to tell us, at the deepest level, about Socrates as a philosopher." ${ }^{\text {B }}$ But then they miss the interesting systematic riddles of what they call Socratic irony-therefore others may prefer a "less exotic" approach, as Ferrari puts it. The classical historical approach leads to murky exegetical problems. For instance, did Socrates really claim he knows nothing, which is different from saying that he is ignorant in a particular case ${ }^{6}$ His main ethical axiom states that virtue is knowledge ${ }^{7}$; hence, if he speaks the truth and knows nothing, he is not virtuous. If he does not speak the truth, and he does know something, he lies, and again, he is not virtuous. Yet he was supposed to be the personification of virtue, like the "Good Bishop," George Berkeley, in his time. ${ }^{8}$

\section{Self-Knowledge and Erroneous Beliefs}

Suppose someone introduces a problem, it does not matter who, to be debated and the Speaker asks for a solution while claiming or tacitly suggesting that she may not know what it is. Yet, she may know, or she is confident that she can find the solution before anyone else does-or prove that no solution exists. The Participants accept the initial challenge, they respond by challenging the Speaker, and after a discussion they propose an answer, which the Speaker duly questions and refutes. The situation is dynamic: the key idea is that the Participants initially believe that the Speaker does not know. When the debate started, they were confident about knowing the solution or at least finding it-this is false confidence, as the Audience sees it: the intended Audience knows the logic of SI and they correctly identify the situationSI has a triangular form. More specifically, we need the idea of an Audience because they, for instance, can act as judges - without them, the debates tend to be endless.

Ever since the idea of Universal Audience, or my intended Audience, emerged it was criticized as too vague and undefined: the Audience has too many roles that are difficult or impossible to systematize. Here the Audience acts as a judge, they are silent observers, and the Participants may hear from the Audience, it all depends

\footnotetext{
5 Ferrari, "Socratic Irony as Pretence," (2008, p. 1). See Vlastos, "Socratic Irony," (1987); Gottlieb, "The Complexity of Socratic Irony," (1992); Vasiliou, "Conditional Irony in the Socratic Dialogues," (1999); Aiming at Virtue in Plato, (2008), and "Socratic Irony," (2013).

${ }^{6}$ Cf. Fine, "Does Socrates Claim to Know that He Knows Nothing?" (2008, p. 49).

7 Zyskind and Sternfeld, "Plato's Meno 89 C: "Virtue is Knowledge'," (1976). "Socrates: Therefore we say that virtue is wisdom [or knowledge; Greek phronesis]: either wisdom in general, or some part of wisdom." Plato, Meno 89a.

${ }^{8}$ See Breuninger, Recovering Bishop Berkeley, (2010, pp. 1-2). Pope famously said he "had every virtue under heaven" (ibid. p. 148).
} 
on the context. Therefore, the Audience is an intuitive notion here: a debate has an audience who is present now or hears about the debate later. ${ }^{9}$

Now, the Speaker invites the Participants to try their arguments again and again, and always she shows that they fail, and the Audience agrees with her. At some point, the process must end, but where and why is unclear-several possibilities exist. The Speaker may (a) reveal the correct solution; she may (b) reach a solution that is better than any of the alternatives; or she may (c) show that, regardless of what the Participants so confidently think and say, no correct solution has emerged, or (d) no such solution exists. The last two cases sound like the most humiliating to the Participants-wild goose chase looks and feels bad. ${ }^{10}$ For instance, the Speaker already knows that the problem is impossible and yet she makes her opponents struggle with it in front of a critical Audience.

To understand the A-type SI, we analyze an epistemic situation where one is supposed to know that one does not know. ${ }^{11}$ The Speaker goads the Participants to explore the problem and the subject matter. She drives them towards defeat and their reluctant confession of ignorance all the time foreseeing what the next argumentative step will be like. However, when she starts the process and, for dialectical purposes, indicates that she does not know the truth the situation remains ambiguous: she may or may not know. These two cases lead to different kinds of dialectical development and have different types of moral implications. Let us first focus on the case in which the Speaker does not know what the solution is. This has two interpretations: the Speaker (1) knows that she does not know (de se); and (2) she does not know but she does not know it (de re), in this case she still thinks she knows-and she says she does not know. ${ }^{12}$ According to the logic of SI, she must initially say she does not know. First, she pretends ignorance; second, she errs. Her ignorance is first explicit but still feigned, and then it is real but implicit. We already stipulated that in both cases the Speaker says she does not know, which is true-in both cases, she does not know.However, the logic of SI ideally entails that the Speaker's belief system is subjectively transparent (de se) in the sense that she always knows what she knows and does not know-this excludes the possibility of (2). To include it would

\footnotetext{
${ }^{9}$ Perelman and Olbrechts-Tyteca, New Rhetoric (1971, p. 35) introduced Universal Audience, which "provides shared standards of agreement by which to measure argumentation." See Tindale, Rhetorical Argumentation, (2004, p. 133); Aikin ("Perelmanian Universal Audience," 2008) tries to save the muchcriticized idea: it is too vague. If SI is an ideal model, Audience is an idealization, too; it resembles Adam Smith's impartial and fully cognizant Ideal Observer; see Firth, "Ethical Absolutism and the Ideal Observer"; see Firth, 1951.-I am grateful to two anonymous referees for explicating this problem.

10 See Piering, "Irony and Shame in Socratic Ethics," (2010).

11 Dynel ("The Irony of Irony," 2017), calls this "veridical irony" but she does not mention SI.

12 De re translates "of the thing" and de se "of oneself." For instance, "fello de se" means an evildoer in respect to oneself; for instance suicide. A person may assume an attitude towards a proposition about herself, knowing that this proposition is about her. Sometimes this is unclear and the proposition requires disambiguation. For instance, "His pants are in fire" may mean myself or someone else. De re attitude focuses on the flaming pants. See Lewis, "Attitudes De Dicto and De Se," (1979)._- "I know that p" concerns my knowledge as if objectively, but "I know that I know that p" concerns me as an epistemic subject. The first expression concerns the world and the second concerns me, an epistemic agent. Obviously, I can know without knowing that I know. I honestly say I do not know his name, although I know it is Patrick-for some reason I blocked the relevant thought in this situation.
} 
complicate the logic of SI considerably. The requirement of such transparency is an example of ideal conditions: real epistemic agents cannot consistently know de se what they know, or they are not immune to de re implicit errors.

In real life, the Speaker may err and falsely believe that she knows while, at the same time letting the Participants believe that she does not know-which happens to be true. She says she does not know when it is true that she does not know, but she does not know it de se. Of course, the logic of SI dictates that the Speaker always pretends she does not know-but now she is right de re. Do the Participants now know more than the Speaker, namely, the Participants know that she does not know-she told them the truth de re-while she does not know it de se? The Participants learned that she does not know-in de re sense they do know it now. But they do not know that she errs, and hence what they do not know will mislead them; that is, they cannot know that the Speaker errs concerning her knowledge. And they cannot utilize what they know because the Speaker will mislead them during the debate when she utilizes her false knowledge. They will lose the debate and, of course, they also lose their initial de re knowledge of the Speaker's ignorance. They knew she did not know but now they come falsely to believe that she knew. This shows that the dictionary definition of the A-type SI is an oversimplification. To say I do not know is not a simple and innocent bluff. Without the assumption of ideal epistemic transparency, the Speaker's victory can be illusory and even harmful.

Suppose that the Participants once entertained the correct belief that the Speaker does not know, when she incorrectly thinks she knows, and they knew it de re, because the Speaker has told them she does not know; hence, their knowledgeclaim is now epistemically justified, too. Yet, this information is misleading and thus harks back to the paradoxical and intractable Gettier's problem of the definition of knowledge as justified true belief, as anticipated by Socrates in Theaetetus (210a). Justified true belief requires an extra condition to make a valid definition of knowledge. Amazingly, this ancient lesson was forgotten until 1963 when Edmund Gettier published his seminal paper and referred to Plato's Theaetetus (p. 201) and Meno (p. 98). ${ }^{13}$ Before Gettier, knowledge was understood as a fully certain belief, in a Cartesian manner, which is not convincing. The definition of knowledge remains an aporia. $^{14}$

What happens when the dialectic proceeds on a false and misleading basis? The Participants may still end up with a true and well-founded answer to the problem, which is to say they now know. The Speaker comes to know what she did not know before, and she will adjust her beliefs to the new cognitive context-but this is impossible when we discuss the B-type of SI: the Speaker always wins. However, it may happen that the Speaker's false beliefs will prevail and thus mislead the

\footnotetext{
13 See Swain, Reasons and Knowledge, (1981, Ch. 5): Defective Justification; Gettier, "Is Justified, True Belief Knowledge?" (1963). For translations, see for instance Chappell, Reading Plato's Theaetetus, (2005); and Plato, Meno,tr. S. G. Chappell.

14 The dialectics may lead to aporia, or an unsolvable problem that we know is not a pseudo-problem. See Rescher, Aporetics, (2009); and Siitonen, Problems of Aporetics, (1989). According to Detweiler, in "Disfiguring Socratic Irony," (2016), aporia is the most Socratic of results: to show that a problem is an aporia, when others argue for a solution, is to win the debate.
} 
Participants to accept a falsehood, in which case they are in the same situation as the Speaker: now nobody knows-this is ironic but does not exemplify SI. Therefore, it is not enough that the Speaker may know, when she says she does not know, she must know that she knows what she knows and what she does not know. Otherwise, the Participants gain nothing from their defeat, and the Speaker's victory is both groundless and hollow.

The case of the implicit error of ignorance is common and difficult to shake, especially in the Speaker's case. She is, ideally, supposed to win all her debates, which makes her own learning processes rare and difficult and does not promote her self-knowledge in the spirit of gnothi seauton. Before B-type SI emerges, the Speaker must, in real life, be in a humble learning position for some time. A baselessly self-confident Speaker is a dangerous teacher-she must know what she does not know and be genuinely skeptical about her own system of beliefs and aware of the restrictions of her cognitive abilities. ${ }^{15}$ Only an ideal Speaker may emerge as if fully grown, like a god, from nowhere.

\section{Dramatic Irony}

The groups of partakers form a triangle: the Speaker who says she does not know, the Participants who do not know, and the Audience who know that the Speaker knows and the Participants do not know. The Participants are ill-fated, as the Audience predicts, because of the superior knowledge and ability of the Speaker. Now the current analysis of SI entails dramatic irony; indeed, SI is a special case of dramatic irony in the sense that the Speaker and the Participants are on the stage, and the Audience knows more than the Participants on the stage as characters. ${ }^{16}$ The Platonic-style dramatic script of the debate dictates the loser. Now we have a scripted theme, or the Speaker's alleged knowledgeableness that the Participants, unlike the Audience, will miss. The Participants are now on the stage together with the Speaker under the gaze of the Audience. Because they know more than some characters on the stage, we have here a straightforward example of dramatic irony: the Audience knows, just like Plato's readers, that the unsuspecting Participants will lose the debate against the Speaker. How can this happen if the topic is open ended or essentially contested? Nevertheless, SI is a subtype of scripted dramatic irony, which is another way of saying that SI is an ideal case. The Speaker will win as the script specifies. Sometimes her victory is hollow and strained, but this is also the case with some Platonic tales of Socrates' predictable successes. But in the case of dramatic irony, we are not allowed to raise moral issues. It is all about drama as

\footnotetext{
15 See Naess, Scepticism, (1967). I met Arne Naess in Micronesia in 2000 and he bitterly complained about people misreading his book. Perhaps this it was his pet Socratic strategy. See also Grayling, Scepticism and the Possibility of Knowledge, (2008).

16 Airaksinen, "Socrates Meets the Crocodile," (2021); Goldie, "Dramatic Irony, Narrative, and the External Perspective," (2007)._-Plato's accounts of Socratic debates have a staged appearance as if they were scripted. The Audience, and Plato's readers, can watch the drama of the debate unfolding. Also, their scripts have certain repetitiveness and in this sense they feel artificial.
} 
fiction, a Platonic play that innocently and amusingly discloses the relative ignorance of the Participants. Many readers find this entertaining. In the paradigmatic cases of dramatic irony, the characters on the stage follow a script that is written so that the Audience may know more than the Participants. However, when we discuss real A-type SI the circumstances change: the characters follow no script and thus they do not act in a play; on the contrary, for the Speaker and the Participants the situation is real and dead serious in the sense that their reputation and self-respect are at stake.

\section{Argumentative Know-How and Educational Effort}

What happens without the script and independently of the dramatic setting? The idea of the Speaker's superior knowledge may no longer apply because such knowledge can hardly exist when the initial problem is an aporia or an essentially contested notion. The only possibility is the superior argumentative and rhetorical skill, or know-how, that the Speaker has and must have if we want to retain the idea of A-type SI as a method. ${ }^{17}$ Therefore, the Audience knows that the Speaker's relevant skills are superior to those of the Participants' and thus she will win-whatever this may now mean. The idea of realistic cases of a B-type SI can be based on superior debating skills (know-how) rather than the knowledge (know-that) of the Speakerbut in such a pragmatic case, we may talk about winning more or less independently of truth. ${ }^{18}$ However, such skills alone are not what we want when we talk about the B-type of SI and rhetoric in the Aristotelian sense. Indeed, we should insist on a close relationship between the true and the persuasive. Otherwise, some victories will be illusory and even unethical.

The requirement of cognitive transparency entails that the Speaker is justifiably confident of what she knows. If she knows that she does not know, she may still will: she finds the answer or she proves that no answer exists. Her know-how, or her argumentative skill and ability, saves her. The Speaker may win in two different ways, using know-that and know-how: she may not know but she knows how to produce the relevant knowledge. We can hardly discuss SI without introducing a distinction

\footnotetext{
17 Rhetoric is sometimes understood as the art of persuasion, when one follows Aristotle (see his Rhetoric): "Aristotle defines the rhetorician as someone who is always able to see what is persuasive (Topics VI.12, 149b25). Correspondingly, rhetoric is defined as the ability to see what is possibly persuasive in every given case (Rhet. I.2, 1355b26f.)." But it is important to notice that the "alleged affinity between the true and the persuasive justifies Aristotle's project of a rhetoric" (Rapp, "Aristotle's Rhetoric," (2010), 4.1 and 4.4).

18 Ryle, The Concept of Mind (1949, Ch 2) is a classic. Know-that indicates propositional knowledge. Know-how produces results that are either cognitive or practical: I know how to produce propositional knowledge or make furniture-know-how requires a special skill and proper method, but the nature of the results depend on the context. Therefore, it is misleading to say that know-how is knowledge of how to do something smoothly and efficiently; know-how refers to ability and skill, and it is knowledge only in an extended or metaphoric sense of the term knowledge. For example, I know how to drive a bike although I do not know how I do it. In Aristotle's practical syllogism the conclusion is action, not a proposition. See Gottlieb, "Practical Syllogism," (2006); and Broadie, "Practical Syllogism," (1968, p. 26).
} 
between know-how and know-that. Suppose we discuss a realistic case: she is mistaken, but if she is a superior debater, she may still convince her opposition and win. She may start a debate-when she mistakenly thinks she knows the solution-and succeed: her favorite falsehood will prevail. However, this is a shallow victory, as the Audience must realize. Know-how can be dangerous, and hence the role of the Audience as a judge is crucial. Abilities and skills can be misused. Therefore, a balance between the perspectives of know-that and know-how is important. Suppose the Speaker has superior argumentative know-how compared to the Participants. Also, her persuasive efforts may allow the Audience to appreciate her performance against the Participants. Yet, this may not be enough: what is the value of the victory of the Speaker, as judged by the Audience, who now assumes the role of wellinformed rational evaluator devoid of partiality and self-deception? It is minimal.

Suppose the value in question is high. We may then call some fair and useful debates Socratic educational efforts by the Speaker-what happens to SI in this case? Why call it education? The losers will learn something about the subject matter and themselves. However, the Speaker's superiority must somehow be guaranteed before she qualifies as a teacher. If this is not the case, we only have a teaching situation in some secondary sense, yet the situation may also satisfy the sufficient conditions of an educational event, as it is easy to see.

SI entails a Speaker who is now a teacher who instructs a group of students who in an overconfident manner may think they can win the debate against the Speaker. ${ }^{19}$ This happens typically when the issue is an essentially contested one but certainly not when they discuss some standard definitions and hard facts. In these cases, the students will come to realize their incompetence and impotence, this they will hear from the Audience. Let us now presuppose the ideal rationality of the students, however immature and incompetent they may otherwise be.

The students must realize they cannot match the superior skill and competence (know-how) of the Speaker as their teacher. Next, suppose the issue is essentially contested, hence they may challenge the teacher-Speaker and hope to go some distance towards success. Perhaps this is an ironic situation? That is, immature students seriously challenge the superior teacher hoping to win a non-winnable case. This is indeed ironic but is it SI? The answer is in the negative, for the following reason. In the standard case of the A-type SI, the Participants do not know enough of the Speaker and they underestimate her thinking assuming that she is their equal-she is not. In a teaching situation, the students are supposed to know both their position and the status of their teacher. A teaching situation is never experienced as a symmetric one: even if the teacher may assume the students' standpoint, or personally simulate it, the students cannot do the same with the teacher's position. They may try to emulate it, but their successes are limited. Such cases are not symmetric and they all know it. Therefore, if the Speaker is teaching, the case no longer unproblematically exemplifies SI-teaching is not a debate, although it may take the form of a debate. Of course, we may say that the Speaker is just "teaching" them, and in this

19 Plato's Socrates is a teacher, see for instance, Magrini, "Dialectic and Dialogue in Plato," (2014); and Mintz, "Why did Socrates Deny that He was a Teacher?" (2014). 
case the idea of SI applies to the case. In this metaphoric sense, close contact with a street bully may "teach" a person a valuable lesson. To call such an event "educational" entails some nasty verbal irony or even a touch of sarcasm.

Eric Detweiler writes about the dangers of SI in a teaching context. Perhaps he wants Socratic irony without irony, or educational irony that deconstructs the traditional teaching situation. But as was said above, when the idea of the A-type SI is applied to teaching, paradoxically it no longer works as irony, except if the teacher pretends not to be a teacher. Can she do it in good faith, that is, to say she does not know? - perhaps not. Detweiler's radical and postmodern idea of teaching may be fine, but it has not much to do with SI. The only irony in his account follows from an idea of teaching that no longer is teaching. We may call this SI in a Pickwickian sense:

In short, it may be that irony's arrival never gives us the chance to be a good host, to extend hospitality. It renders us, rather, a pedagogical hostage, stuck following after it rather than leading it or using it to lead-thus interrupting one etymological sense of "pedagogue," the one who leads ("agogos") the child ("pais"). In terms of pedagogical authority, then, what I am after is a "Socratic irony" that is not used by a masterful Socratic figure to lead students into orderly anamnesis and a deferral of deliberative authority to the teacher, but that disorders and deauthorizes "teacher" and "student" alike. It is, then, a linguistic violence to be weathered by us all even as it leads us to question the limits of such categories as "us" and “all." (Detweiler, "Disfiguring Socratic Irony," 2016, p. 167)

Real cases of SI make the necessity of teaching and learning obvious: all the agents involved in the debate may benefit from it. Knowledge claims do not permit full certainty, or certainty is not part of the definition of knowledge as a justified, true belief, plus something else (as specified by the Gettier condition). This brings about a subtle but realistic moral problem: how certain should the Speaker be when she says she does not know and starts the dialectical process based on the A-type SI? She may not know with full certainty, whatever she currently thinks of her own beliefs, and she should realize that her knowledge claims may be false independently of what she has done to verify them. She now has two alternatives: she is ready to learn from the Participants or she is not. The second alternative implies that she is subjectively certain, or what is the same, she unconditionally trusts the validity of her positive and negative knowledge claims, "I know that p" as well as "I know that I know p." Think of "I am certain that I do not know p." This is never, or only in some special cases, a justified epistemic attitude. In the real case, such subjective certainty is a cognitive and psychological flaw. All this leaves room for teaching and learning.

Therefore, at least in some cases, one is bound to learn from others. Think of essentially contested social issues. No one can explain and discuss these in any detail at the same avoiding bitter challenges. One cannot claim one's ideas are always true and beliefs certain, on the contrary, they stay at the level of suggestions and proposals, or hypotheses, regardless of what one thinks of them. Full certainty is then fictional. Counterexamples exist but they cannot be generalized: if the Speaker and the Participants, including the Audience, share partisan 
social values and hand-picked background information, they may agree and reach a consensus and subjective certainty. Perhaps the problem concerns some well-defined details of a larger issue-but such artificially restricted cases are of minor significance here. They say they know but here the blind lead the blind. Cross-cultural debates are especially tricky and inconclusive; they can be called practical aporias.

\section{Divine Irony}

Socrates says his argumentative midwifery is a gift of gods and "heaven's work" (Theaetetus 150d). In this respect it is different from female midwifery, in opposition to what Socrates says (150b): a divine gift does not entail learning, unlike practical medical skills. ${ }^{20}$ Socrates looks like a semi-divine agent, which is to say that his ironies are divine as well. Again, we move at the level of idealizations, or perhaps metaphors that hide certain fictive religious ideas-naively religious believers may take all this prophetic imagery literally, though. However, B-type SI entails that the Participants do not understand whom they confront and challenge: they have no hope of overcoming a superior being, in this case, the Socratic Speaker. On the contrary, they are now on their way to self-humiliation in the eyes of the Audienceand ultimately in their own eyes as well. This may sound conventional, and it is. It reminds us of the classic Westerns and their essential dramatic irony: the villain and the hero meet and duel in the final scene, and the villain will lose, as the audience knows-but this also applies to divine irony. It again evokes Socrates' semi-divine status.

Divine irony is what emerges from debates and other competitive transactions with gods when a human agent fails to admit his inherent weaknesses and thus becomes guilty of hubris. ${ }^{21}$ Mark Shea in National Catholic Register explains divine irony:

During the Easter season, which lasts until Pentecost Sunday, it is easy to remember that we tread in a minefield-especially as we recall the Passion. This is as it should be, for a culture that lives in the shadow of the Holocaust feels a twinge of uneasiness when we read in Matthew 27:25: "And all the people answered, His blood be on us and on our children!" The uneasiness springs from what many people feel sure Matthew was getting at-namely that the Jewish mob called down a curse upon their people and that God heard their "prayer." (Shea, "Divine Irony," 2010)

He concludes: "So we know what the passage doesn't mean. What, though, does it mean? I would submit that it is recorded by Matthew as an example of divine irony."

\footnotetext{
20 See Wengert, "The Paradox of the Midwife," (1988).

21 See Holland, Divine Irony, (2000). Divine irony is an essential component of hubris, or defiance of the gods, leading to nemesis. It is situationally ironic to try to challenge a godhead.
} 
We read, "God heard their "prayer"" and the sublime verbal irony emerges that is as cruel as it is divine.

How does this relate to the B-type SI? Divine irony is not only based on superior knowledge and debating skills, or any form of fair and truthful rhetoric; it is also based on superior power, and we already have seen that the B-type SI is likely to be based on power relations as well, especially its know-how version: know-how entails power. $^{22}$ If it does not, how can the Speaker win so consistently and how can the Audience predict the results, even when the topic is an essentially contested issue? The Speaker must somehow be capable of overcoming her opposition, or the Participants, and convince the Audience, but this presupposes her power over others. The idea of divine irony explains this in a way that is at the same traditional, fictional, and perhaps precarious.

Think of Descartes' Christian God who denies us the certainty of the impossibility of squaring the circle and other similar mathematical truths. ${ }^{23}$ Hobbes claimed that he squared the circle, to John Wallis' dismay. They debated the issue for years and Hobbes of course lost the fight, to his dismay-he never recognized his defeat unlike the learned members of the Audience. ${ }^{24}$ Wallis might also reject Descartes' claims concerning the achievements of his omnipotent God when arguing against Hobbes' chances of convincing him of the reality of such a miracle as squaring the circle. Nevertheless, Wallis must lose, as the Cartesian Audience predicts, regardless of his valid geometrical arguments and his belief that mathematical truths are necessary and therefore certain. If God is omnipotent, and we take this theological idea seriously, he can change the rules of the game and so any attempt to argue against Him is a farce. In a debate about geometry, he can modify the rules defined by Euclid, and therefore he can square the circle. If he cannot, he is not omnipotent, which is heresy. This may sound far-fetched but it logically follows from the idea of omnipotence. Certainly, not all godheads are in this way omnipotent. They are more capable and powerful than humans, but for instance Greek gods were far from omnipotent. They cannot fight destiny or moira, and they struggle against each other. ${ }^{25}$ But regardless of their status in this respect, divine irony is a fact when one rebels against gods.

If this rather Medieval Christian example sounds dubious, we can think of a game between a supercomputer's Alpha Zero program and human chess or Go master. The program can win all types of combinatorial games of perfect information against a human opponent. Ideally, the program will check all the possibilities, or in real life enough of them. Artificial intelligence may then assume the place of gods: the superior computing power of AI constitutes what I call unfair advantage, although this applies only to computable cases. The irony of "Resistance is futile" (Borg, Star Trek) is obvious. The situation is different, of course, when we discuss topics and

\footnotetext{
22 "Knowledge is power," as Francis Bacon said; see Potter, "Power and Knowledge," (2010).

23 See Miller, "Descartes, Mathematics, and God," (1957).

24 Jesseph, Squaring the Circle, (1999).

25 See Solomon, "On Fate and Fatalism,” (2003).
} 
debates that involve, say, metaphors and normative sentences as well as essentially contested issues.

God will win any debate- but not only because of his omniscience but omnipotence, which is to say that "he is able to perform any action." ${ }^{26} \mathrm{He}$ knows and can make things happen, and even if one believes in his powers, one may not realize the extent of them. SI is now based on divine powers that win debates even when they are prima facie unwinnable. Such godhead will succeed in his special way, a powerful Speaker may win in her way; for instance, she chooses the terms and premises so that she will win in the end, or she convinces the Audience and the Participants that her view is superior to theirs, even in the case where the topic is essentially contested. A minor miracle occurs again and again: the Speaker wins. He cannot losethis is a source of B-type SI. But the human Speaker is an ideal case, God's powers are real-as religious people would say. Thus, Plato's Socrates must act under the guidance and protection of gods.

A-type divine irony exists, too. We need to look outside of the Christian context. Non-perfect and less than omnipotent gods may find such irony desirable. King Pentheus debates with Bromius in Thebes calling him an upstart, minor godhead whom he is not going to worship. The god maintains he indeed is a god, or at least send by the god, and hence he insists on his rites. Deny them from him and you will pay the price. The divine and dramatic irony are obvious here, but how about SI? First, Bromius behaves as if he were an ordinary traveler and messenger and misleads Pentheus to believing that he, as the king, can win. This entails A-type SI. However, the audience, including the chorus, can predict the outcome: Bromius will convince Pentheus about his divinity, which will lead to fresh knowledge and death. Pentheus will learn a lesson when Bromius wins, and this is B-type SI. However, the god can use rather practical methods to win the argument. He goes as far as killing Pentheus; he is responsible for his death even if the killing is done by his Maenads, a group of ecstatic bacchant women, including Theban women-this is another telling fact. Among them is Pentheus' mother, Agaue, which makes the story bitterly sarcastic. She says "The honour of the first blow goes to me/In the dancing I'm called blessed Agaue." She thinks they killed a young bull or a lion. ${ }^{27}$

Obviously, SI contains traces of divine irony if the Speaker is imbued with powers that are analogous to divine power. A Socratic hero may need extra-logical and proto-divine powers first to make the Audience's pre-knowledge possible and then convince the Participants during any possible debate. Here is an example that is as telling as it is trivial. Suppose the Speaker says Uighurs are terrorists, which is an essentially contested thesis, what can the Speaker do to win the debate in a way that satisfies the requirements of B-type SI? The Audience knows beforehand that she will win, although the Participants cannot yet accept the fact, and the Speaker refuses to give them an initial hint of her superiority, on the contrary, she plays a meiotic game.

\footnotetext{
26 Frigerio and Florio, "Two Omnipotent Beings?" (2015, p. 309).

27 Euripides, Bacchae, 1460-70 (English text), 1170-80 (Greek text).
} 
The situation resembles jury selection: he who selects the jury will be on the winning side. The Speaker may have the power to choose the Participants or at least postpone the debate against a wrong opponent. Once she has chosen a suitable group she can win; against a wrong group she may not stand a chance-it will be a dead end. However, for the Speaker to win, we do require that the Participants accept the starting points, values, and other such premises, or the crucial presuppositions and presumed facts. She makes the starting position favorable from her point of view, and she makes them accept her argumentative steps, however dubious they may look to the Participants-reveals the full SI of the case. ${ }^{28}$ How this kind of unfair argumentative advantage is achieved is a moot problem that we cannot discuss in detail here. Think of Stalin arguing for his ideas of developing the economy of the USSR with his underlings. Why does he win? How do we know he will win? In such special cases, know-how and power are decisive factors, and therefore a combination of divine irony and SI is evident here. Such debates can hardly be called fair.

In real life, the Speaker can consistently and predictably win a debate over an essentially contested issue, or even an aporia, against Participants only if she has an unfair advantage over them. We may call the required advantage "unfair" because it is extra-rational: guidebooks of rational debate miss this point. Yet one needs it when the topic does not concern facts, logic, or definitions but essentially contested problems. The rules of rational debate need not apply when one's winning position is in question; vague compromise may be possible, but here one is interested in winning. However, the Speaker is a guaranteed winner if and only if she can use some extra-rational means including, for instance, suitable premises and values, verbal tricks, and convincing-looking but ultimately misleading arguments. The Participants must accept ad hoc premises and superfluous conclusions. Then and only then can she consistently win, just like the Audience predicts.

Therefore, if we compare her with a divine power wielder, the Speaker can no longer be a fully epistemically rational and consistent ethical player or a virtuous agent who acts in good faith. In terms of divine irony, she is now like a god, or she always plays by her own rules. This is know-how and power, and given her superiority, she also can deflect the accusations of being less than a virtuous agent. Her superior status as a debater grounds her false claim to virtue; if she knows better than anybody else what virtue is and who is virtuous, how could she not be virtuous herself? Of course, all of this is verbal trickery and non sequitur. Such a conclusion is meta-ironic: SI invites an ironic treatment of irony. Of course, one can and should block this by insisting on fairness and truthfulness.

The ironic interpretation of SI requires two steps: First, the Participants challenge a superior talent, the Speaker, as if they were equals and, thus, they think they can win. Second, the winner looks virtuous because of her superior talent, know-how, rhetoric, and power, or in other words, she looks virtuous exactly because she is not virtuous. She never tells the opposition who she is, what her powers are like, or how

\footnotetext{
28 Plato's Socrates sometimes utilizes fallacious means of argumentation (Sprague, Plato's Use of Fallacy, (1962); cf. Stone, "Denying the Antecedent," (2012). He also chooses the initial premises. One may also suspect that he picks the right opponents.
} 
she did it. Here is the true irony of SI. We have no reason to be as optimistic about the ethics of SI as Julie Piering-she concludes,

Socratic irony is of the riddling variety and the shame that it produces is not intended to belittle the interlocutor's sense of self. Instead, shame is an appropriate response to the realization that one's life is unexamined and possibly vicious. Therefore, the real problem with Socratic irony lies not with its use, but its failure rate. (Piering, "Irony and Shame in Socratic Irony," 2010, p. 273)

She is right when she says the shame factor is not crucial. To lose in a debate is not shameful as such, but to argue badly is humiliating. The problem is the Dutch Book on the Participants: they cannot win or they cannot win in the long run. ${ }^{29}$ In reallife cases, the Speaker must rely on her external sources of power, or she possesses an unfair advantage, to be regularly, if not always, on the winning side. In real life, all individual cases of struggle are essentially unpredictable as to their results, or "failure rate" is what it is. Only a loaded dice can guarantee the desired result. Only Plato's Socrates can win all the time-his B-type irony ultimately is divine irony in disguise, his martyrdom included. Or, if we do not believe in the myth of historical Socrates, we must say the B-type SI is grounded both on a set of idealizations concerning the fairness and truthfulness of the situation and the virtuous characteristics of the players of the argumentation game and debate. In real life, no one can win all fair debates. They are not like Wild West duels in movies, they are more like reallife boxing matches. In the end, even Muhammad Ali will lose. A permanent winning strategy is an idealization, but even then it is worth examining and explicating.

Funding Open Access funding provided by University of Helsinki including Helsinki University Central Hospital.

Open Access This article is licensed under a Creative Commons Attribution 4.0 International License, which permits use, sharing, adaptation, distribution and reproduction in any medium or format, as long as you give appropriate credit to the original author(s) and the source, provide a link to the Creative Commons licence, and indicate if changes were made. The images or other third party material in this article are included in the article's Creative Commons licence, unless indicated otherwise in a credit line to the material. If material is not included in the article's Creative Commons licence and your intended use is not permitted by statutory regulation or exceeds the permitted use, you will need to obtain permission directly from the copyright holder. To view a copy of this licence, visit http://creativecommons.org/licen ses/by/4.0/.

\section{References}

Aikin, S. 2008. Perelmanian universal audience and the epistemic aspirations of argument. Philosophy \& Rhetoric 4: 238-259.

Airaksinen, Timo. 2021. Socrates meets the crocodile, or the ironies of Brecht's and Wuolijoki's Herr Puntila und sein Knecht Matti. Finnish-German Yearbook of Political Economy 3: 77-96.

\footnotetext{
29 Dutch Book in gambling: a set of odds and bets that guarantees one side a profit, whatever happens in the game. This is a characteristic feature in B-type SI: the dice is loaded.
} 
Aristophanes, Clouds. Tr. by “The Atticist.” 2021 (https://aristophanes-clouds.gr/).

Aristotle, The art of rhetoric. Tr. by Robin Waterfield. 2018. Oxford: Oxford University Press.

Breuninger, Scott. 2010. Recovering bishop Berkeley. London: Palgrave.

Broadie, Alexander. 1968. The practical syllogism. Analysis 29: 26-28.

Chappell, Timothy. 2005. Reading Plato's Theaetetus. Indianapolis: Hackett.

Detweiler, Eric. 2016. Disfiguring Socratic irony. Philosophy and Rhetoric 49: 149-172.

American heritage dictionary (https://www.ahdictionary.com/word/search.html?q=irony). Accessed 8.9.2021.

Dynel, Marta. 2017. The irony of irony: Irony based on truthfulness. Corpus Pragmatics 1: 3-36.

Euripides, Bacchae. Tr. Ian Johnston. 2020. (http://johnstoniatexts.x10host.com/).

Ferrari, G.R.F. 2008. Socratic irony as pretense. Oxford Studies in Ancient Philosophy 34: 1-33.

Fine, Gail. 2008. Does Socrates claim to know that he knows nothing? Oxford Studies in Ancient Philosophy 35: 49-88.

Firth, Roderick. 1951. Ethical absolutism and the ideal observer. Philosophy and Phenomenological Research 12: 317-345.

Frigerio, Aldo, and Ciro Florio. 2015. Two omnipotent beings? Philosophia 43: 309-324.

Gettier, Edmund. 1963. Is justified true belief knowledge. Analysis 23: 121-123.

Goldie, Peter, "Dramatic irony, narrative, and the external perspective." Royal Institute of Philosophy Supplement 60: 69-84.

Gottlieb, Paula. 1992. The complexity of Socratic irony: A note on professor Vlastos' account. Classical Quarterly 42: 278-279.

Gottlieb, Paula. 2006. The practical syllogism. In The Blackwell Guide to Aristotle's Nicomachean Ethics, ed. Richard Kraut, 218-233. Oxford: Blackwell.

Grayling, A.C. 2008. Scepticism and the possibility of knowledge. London: Continuum.

Holland, Glen. 2000. Divine irony. Plainsboro: Susquehanna University Press.

Jesseph, Douglas M. 1999. Squaring the circle. The war between Hobbes and Wallis. Chicago: University of Chicago Press.

Lewis, David. 1979. Attitudes de dicto and de se. Philosophical Review 88: 513-543.

Magrini, James Michael. 2014. Dialectic and dialogue in Plato: Refuting the model of Socrates-as-teacher in the pursuit of authentic paideia. Educational Philosophy and Theory 46: 1320-1336.

Miller, Leonard G. 1957. Descartes, mathematics, and God. Philosophical Review 66: 451-465.

Mintz, Avi I. 2014. Why did Socrates deny that he was a teacher? Locating Socrates among the new educators and the traditional education in Plato's Apology of Socrates. Educational Philosophy and Theory 46: 735-747.

Naess, Arne. 1967. Scepticism. London: Routledge \& Kegan Paul.

Nathan, Daniel. 1992. Irony, metaphor, and the problem of intention. In Intention and Interpretation, ed. Gary Iseminger, 183-202. Temple University Press.

Perelman, Chaim, and Lucie Olbrechts-Tyteca. 1971. The new rhetoric. London: University of Notre Dame Press.

Piering, Julie. 2010. Irony and shame in Socratic ethics. International Philosophical Quarterly 50: 473-488.

Plato, Meno. Tr. by Sophie Grace Chappell. https://www.academia.edu/13448466/Platos_Meno_a_new_ translation. (Accessed 8.16.2021).

Plato, Theaetetus. Tr. by John McDowell. 2014. Oxford: Oxford University Press.

Potter, Garry. 2010. Power and knowledge. A dialectical contradiction. Journal of Critical Realism 9: 133-154.

Rapp, Christof. Aristotle's rhetoric. The Stanford Encyclopedia of Philosophy (Spring 2010 Edition), Edward N. Zalta (ed.), https://plato.stanford.edu/archives/spr2010/entries/aristotle-rhetoric/.

Rescher, Nicholas. 2009. Aporetics: Rational deliberation in the face of inconsistency. Pittsburgh: Pittsburgh University Press.

Rorty, Richard. 1989. Contingency, irony, and solidarity. Cambridge: Cambridge University Press.

Ryle, Gilbert. 1949. The concept of mind. London: Hutchinson.

Shea, Mark. 2010. Divine irony. National Catholic Register (http://www.mark-shea.com/di.html).

Siitonen, Arto. 1989. Problems of aporetics. Helsinki: Annales Academiae Scientiarum Fennicae.

Solomon, Robert C. 2003. On fate and fatalism. Philosophy East and West 53: 435-454.

Sprague, Rosamond K. 1962. Plato's use of fallacy: A study of the Euthydemus and some other dialogues. London: Routledge and Kegan Paul. 
Stone, Mark A. 2012. Denying the antecedent: Its effective use in argumentation. Informal Logic 32: 327-356.

Swain, Marshall. 1981. Reasons and knowledge. Ithaca: Cornell University Press.

Tindale, Christopher W. 2004. Rhetorical argumentation: Principles of theory and practice. London: Sage.

Vasiliou, Iakovos. 1999. Conditional irony in the Socratic dialogues. Classical Quarterly 49: 456-472.

Vasiliou, Iakovos. 2008. Aiming at virtue in Plato. Cambridge: Cambridge University Press.

Vasiliou, Iakovos. 2013. Socratic irony. In The Bloomsbury Companion to Socrates, ed. John Bussanich and Nicholas D. Smith, 20-33. New York: Continuum.

Vlastos, Gregory. 1987. Socratic irony. Classical Quarterly 37: 79-96.

Wengert, R.G. 1988. The paradox of the midwife. History of Philosophy Quarterly 5: 3-10.

Xenophon. Apology of Socrates. In Xenophon in Seven Volumes, 4. Tr. by O. J. Todd. 1979. Cambridge, MA: Harvard University Press, and London: William Heinemann. (http://www.perseus.tufts.edu/ hopper/text?doc=Perseus:text:1999.01.0212).

Zyskind, Harold, and R. Sternfeld. 1976. Plato's Meno 89 C: Virtue is knowledge. A hypothesis? Phronesis 21: 130-134.

Publisher's Note Springer Nature remains neutral with regard to jurisdictional claims in published maps and institutional affiliations. 